\title{
Digital Literacy Development Trends in the Professional Environment
}

\author{
Andriushchenko Kateryna \\ Kyiv National Economic University, Kyiv, Ukraine \\ https://orcid.org/0000-0002-6274-5310 \\ Rozhko Oleksandr \\ Taras Shevchenko National University, Kyiv, Ukraine \\ https://orcid.org/0000-0001-8415-2084 \\ Tepliuk Mariia \\ Kyiv National Economic University, Kyiv, Ukraine \\ https://orcid.org/0000-0001-6823-336X \\ Semenyshyna Iryna \\ State Agrarian and Engineering University, Podilia, Ukraine \\ https:// orcid.org/0000-0001-9300-8914 \\ Kartashov Evgen \\ University of Educational Management, Kyiv, Ukraine, \\ https://orcid.org/0000-0001-6522-5508 \\ Liezina Anastasiia \\ Kyiv National Economic University, Kyiv, Ukraine \\ https://orcid.org/0000-0003-0516-6598
}

\begin{abstract}
This article describes the impact of digital literacy on the professional environment, which allows people to create and share digital content. It also describes how digital literacy can be used communicate and solve problems for effective and creative selfrealization in education, work and social. There are 3 models of digital skills that are largely mutually complementary: DigCompEdu 2018, EU DigComp and Target Competency Model 2025. These models describes changes in the working conditions and requirements for the employee in the context of digitalization. New technologies in teaching digital skills that are continuous, social, personalized and focused on the needs and interests of the students are proposed. The combination of various educational technologies, training formats and technical innovations into a single educational system has also been justified. The improvement in the quality of digital education is due to better data analysis and forecasting, the development and the launch of advanced
\end{abstract}


educational products which uses artificial intelligence techniques. Improvements in forecasting tools enable a better understanding of digital transformation in various departments and ensure their interaction.

Keywords: digital education; competencies; skills; learning support tools; gamification; chatbot

\section{Introduction}

The Fourth Industrial Revolution has led to the widespread dissemination of digital technology, where the use of artificial intelligence, robotics, virtual reality and other innovations have had a powerful impact on the nature of training and work. In 2018, at the World Economic Forum in Davos, changes were made to the methodology for calculating the annual Global Competitiveness Index of countries. The timeliness, expediency and justification of making changes in the indicated methodology were caused by the rapid expansion of digital technologies, which significantly affects the dynamics of the world economy. The new methodology for rating the competitiveness of countries emphasizes the role of human capital, innovation, sustainability and speed, and the ability to respond to change, not only as a driving force, but also as determinants of the country's economic success (Levy \& Murname, 2003; Aesaert et al., 2014).

Digitalization of the economy has led to the penetration of technology into the working environment and personal space of each person. Nowadays the pace of digitalization exceeds the development of skills in the field of digital media applications for most people. Therefore, the issue of digital fluency of the population, especially in the professional environment, is rising. However, despite the scientific work on the definition of "digital economy", there is no holistic scientific concept explaining the essence and peculiarities of its functioning. At the same time, it can be said with confidence that more research endeavors are based on understanding the knowledge economy and its importance for the development of economic activities. In this regard, an urgent scientific task is to develop the development trends in the professional environment of digital literacy. In the current conditions of functioning and dynamic development, the business environment is characterized by the attraction of traditional and intellectual resources, which are the basis of business activity (Ibrahim et al., 2019).

Digital fluency is determined by the set of knowledge and skills that are necessary for the safe and effective use of digital technologies and the Internet (Voogt et al., 2012). The basis of digital fluency is digital competencies which is the ability to solve various problems in the field of use of information and communication technologies (ICT). It also includes the possibility to use and create content using digital technologies, including searching and sharing information, answering questions, interacting with other people, and computer programming. The European Commission, in its definition of digital competency, prepared as part of the Digital Education Action Plan (DEAP), emphasizes the importance of the conscious and responsible use of digital 
technologies in education, at work and in public life. Digital competency should include digital collaboration, security and problem solving (Microsoft, 2018).

Digital fluency includes the personal, technical, and intellectual (digital) skills that are needed to live in a digital world. By digital skills, we mean established, automatic models of behavior based on knowledge and skills in the use of digital devices, communication applications and networks for accessing and managing information (Levy et al.,2003). Digital skills allow people to create and share digital content, communicate and solve problems for effective and creative self-realization in education, work and social activities in general.

This paper uses a wide range of general and special research methods: historical - in the process of studying modern views on the understanding of digitalization in economic theory; structural analysis - to streamline the conceptual apparatus of the digital economy; scientific generalization - in the systematization of various elemental combinations of the use of digital trends and the comparison and analysis of trends to study trends in digital transformation with the identification of possible areas of application of foreign experience in improving existing approaches.

\section{Digital skills in everyday life}

The widespread use of digital technologies in everyday life changes the interaction with the environment. The ways of accessing various services, information, knowledge are changing, and this interaction is intensifying through various channels: social networks, online services, shopping on the Internet, watching video content, etc. Digital skills are becoming the key to living in the digital environment (Moller et al., 2012). They allow you to increase efficiency and reduce the time it takes to solve problems in the digital world, make a person's life more comfortable and open opportunities for personal and professional development. Poor Internet skills is one of the common reasons for refusing to use the Internet in the field of the use of information and communication technologies (ICT).

\section{Digital skills at work}

The importance of digital skills for work and social inclusion is growing. The rate of acquiring such knowledge will determine the success of a person's life and the prospects of his or her employment. According to Microsoft, 65\% of today's school and university students will do work that does not exist yet (Microsoft, 2018). For example, professions such as virtual living environment designers, robotics attorneys, biohackers, or IoT data analysts will appear. A significant number of employees with digital competencies at different levels in the company will provide a competitive advantage (Kefela, 2010).

In the corporate world, 'digital champions' companies stand out, in which the level of digital skills for employees is much higher than the average for the market (Eshet-Alkalai, 2004). This applies not only to specialized employees whose work is related to ICT, but also to the entire staff of the company and its management. Such companies are more effective in their activities, particularly 
in connection with using more efficient business models that are appropriate to the changing needs of the digital world. They have a shorter time to market goods and services, using digital marketing and techniques of start-up companies. They have an efficient cost structure through the use of technology platforms. They have high quality digital products that provide investment in digital talent and a high level of customer satisfaction with product quality through personalized offers and individual digital experiences. It is also believed that the success of these 'digital champions' is due to three key elements (Carnevale et al.,2013): investments in digital technologies account for at least $5 \%$ of operating expenses; assigning more than $10 \%$ of employees to roles that require professional digital skills and the use of digital technology in the business functions of companies.

\section{Literature review and problem statement}

Given how quickly the development of scientific and technological progress takes place, information and communication technologies (ICT) are the core of economic developments. Information and communication technologies are the basis for knowledge-based innovations. Innovations are developed and implemented by people, which is why it is very important for company personnel to be capable of developing and generating new ideas, as well as their implementation (Andriushchenko et al., 2019a). Employees need not only to be good specialists and possess hard skills, but also have digital skills, as well as having sufficient soft skills to adapt to the changes in the external environment (Aesaert et al., 2014).

21st century skills should include communication skills, digital fluency, acceptance of responsibility, problem solving, critical thinking, creativity and productivity (Voogt et al., 2012). There is a need for the identification and development of modern competencies and methods of employee training, as well as for self-development, and effective participation in the development of the company (Ananiadou et al., 2009). Lewin and McNicol argue that the growing influence of globalization and the digitalization of society led many to accept that digital fluency is required to succeed in the workplace (McNicol, 2015).

The main thing is the awareness to move away from the framework of simple technical use. The ability to learn and function in a technological society is much more important than owning a particular program or software (Ahmad et al., 2004). The researchers approach digital literacy as: (1) the ability to use innovative technologies to solve cognitive tasks at work; (2) the possession of skills that are not necessarily technology-oriented, as they may not apply to the use of any specific software; (3) possession of skills that form Higher Order Thinking Skills (HOTS) and (4) possession of skills related to cognitive processes contributing to the lifelong learning of employees. In most cases, these concepts include both the main parts (e.g. computer, ICT, Internet, multimedia) and the complementary part of specific knowledge (e.g. competence, literacy, skills) (Hatlevik et al.,2015). 
Van Deursen proposed a number of 'digital skills' concepts, which included technical or media aspects (average skills), and material or substantive aspects (skills related to the content). Subsequently, that work was supplemented by other skills, namely operational, informational, communication, and strategic. A formal assessment was carried out, which identified a gap in the research. Thus, the purpose of this study is to determine the ways to solve the issue of digital fluency in a professional environment, taking into account globalization and the constant development of scientific and technological progress. In this study, the authors are interested to understand how the development of digital literacy, including the launch of advanced educational products, affects the improvement in the quality of work of employees and how to combine various educational technologies, training formats and technical innovations into a single educational system (Van Deursen et al., 2016).

\section{The Study}

Currently, various government authorities, consulting companies and researchers have developed various models of digital competencies/skills, which are largely mutually complementary. However, we will focus on only three of them, which, in our opinion, reflect the structure and interconnection of individual types of digital competencies/skills.

\subsection{DigCompEdu 2018: European Digital Competency Model for Education}

EU activities in the field of developing digital skills of the population are based on the EU Digital Competence Framework for Educators (Figure 1).

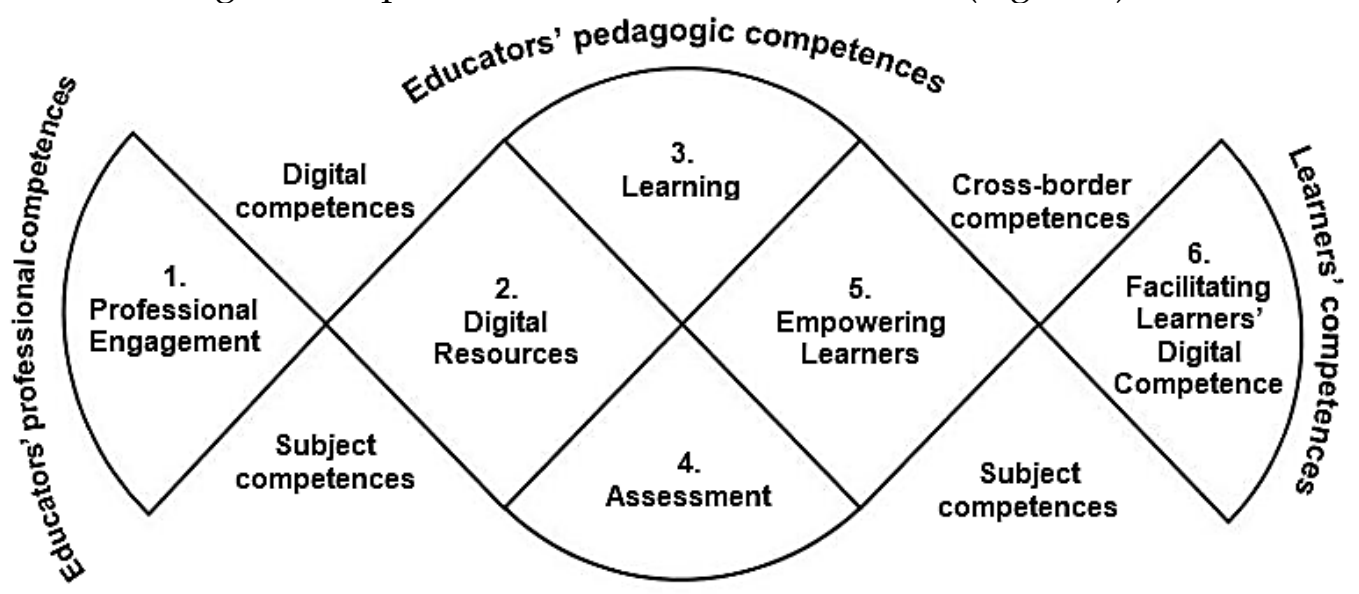

Figure 1: Layout of the European Digital Competencies Model for Education Formed: by authors about 
Under the European Union's Digital Education Development Plan (DEAP), efforts are being made to formulate a new vision of digital

competencies, which are concentrated in three key areas: (1) improving the use of digital technologies in teaching and learning; (2) the development of the skills which are necessary for digital transformation; and (3) reliance on analysis and forecasting based on data in education. The digital skills that underlie digital competencies can be divided into user and professional (Andriushchenko et al., 2020). Custom skills can further be classified include basic and derivative skills. Basic digital skills are associated with functional literacy in the use of electronic devices and applications. They are necessary for access and use of digital devices and online services. Moreover, they are critical for everyone. They include the ability to work with various technical devices, files, the Internet, online services, and applications. Basic skills also include psychomotor skills. For example, the ability to type on the keyboard (the development of fine motor skills) or working with touch screens (the development of gestures).

Derived digital skills are associated with the ability to consciously apply digital technology in a relevant context at home and in the workplace. Mastering such skills is aimed at the effective and meaningful use of digital technologies and obtaining practical results. These skills include creative skills for working in online applications and digital services (social networks, instant messengers, information portals), the ability to create digital content and, the ability to work with information (collect, structure, verify for reliability, store, protect data) (McKinsey Global Institute, 2018).

Specialized professional digital skills which are required for solving complex professional tasks in the digital environment are skills that underlie high-tech professions such as programmers, developers, web-designers and big data analysts. It is necessary to get a special education for their development. This can also include teamwork, creativity, and critical thinking.

\subsection{EU DigComp}

The Digital Competence Framework for Citizens proposes a detailed classification of digital competency, which includes 5 areas and 21 digital competencies that are required by all citizens (Table 1). This classification is applied in 21 countries of the European Union and provides recommendations for educating people and developing policies in the field of digital economy development. The five areas are: information processing, online communications, transactions and financial management, creation of digital content, and using digital problem-solving tools. 
Table 1: Digital Competency List

\begin{tabular}{|c|c|}
\hline $\begin{array}{l}\text { Areas of } \\
\text { competences }\end{array}$ & Competences \\
\hline \multirow[t]{3}{*}{$\begin{array}{l}\text { 1. Information } \\
\text { literacy }\end{array}$} & $\begin{array}{l}\text { 1.1 View, search and filter data, information and digital } \\
\text { content } \\
\text { To formulate the need for information, to search for data in a } \\
\text { digital environment, to have access to content. Create and } \\
\text { change your own information retrieval strategies. }\end{array}$ \\
\hline & $\begin{array}{l}\text { 1.2 Evaluation of data, information and digital content } \\
\text { Analyze, compare and critically evaluate the reliability of } \\
\text { data sources, information and digital content. }\end{array}$ \\
\hline & $\begin{array}{l}\text { 1.3 Data, information and digital content management } \\
\text { Organize, store and retrieve data, information and content in } \\
\text { a digital environment. Organize and process them in a } \\
\text { structured environment. }\end{array}$ \\
\hline \multirow[t]{6}{*}{$\begin{array}{l}\text { 2. Communication } \\
\text { and cooperation }\end{array}$} & $\begin{array}{l}\text { 2.1 Interaction through digital technology } \\
\text { Interact through various digital technologies and identify } \\
\text { appropriate digital communication tools in conte1xt. }\end{array}$ \\
\hline & $\begin{array}{l}\text { 2.2 Exchange through digital technology } \\
\text { Share data, information and digital content with others } \\
\text { through appropriate digital technologies. Act as an } \\
\text { intermediary exchange. }\end{array}$ \\
\hline & $\begin{array}{l}\text { 2.3 Civic participation through digital technology } \\
\text { Participate in society through the use of public and private } \\
\text { digital services. }\end{array}$ \\
\hline & $\begin{array}{l}\text { 2.4 Collaboration using digital technology } \\
\text { Use digital tools and technologies for collaboration, as well as } \\
\text { for the joint production of resources and knowledge. }\end{array}$ \\
\hline & $\begin{array}{l}\text { 2.5 Etiquette in the network } \\
\text { Know the rules and norms of behavior in the process of using } \\
\text { digital technologies and communication in digital } \\
\text { environments. Adapt communication strategies to a specific } \\
\text { audience. Understand and take into account cultural and } \\
\text { generational diversity in the digital environment. }\end{array}$ \\
\hline & $\begin{array}{l}\text { 2.6 Managing Your Digital Identity } \\
\text { Create and manage one or more digital identities. Have the } \\
\text { opportunity to protect your reputation. }\end{array}$ \\
\hline \multirow[t]{4}{*}{$\begin{array}{l}\text { 3. Creating digital } \\
\text { content }\end{array}$} & $\begin{array}{l}\text { 3.1 Creation and development of digital content } \\
\text { Create and edit digital content in various formats. }\end{array}$ \\
\hline & $\begin{array}{l}\text { 3.2 Integration and processing of digital content } \\
\text { Modify and improve the quality of information and content, } \\
\text { integrate them into a single set of knowledge to create new } \\
\text { content. }\end{array}$ \\
\hline & $\begin{array}{l}\text { 3.3 Copyrights and licenses } \\
\text { Understand how copyrights and licenses for data, } \\
\text { information and digital content are being used. }\end{array}$ \\
\hline & $\begin{array}{l}\text { 3.4 Programming } \\
\text { Plan and develop clear and consistent teams for computing } \\
\text { systems to perform specific tasks. }\end{array}$ \\
\hline 4. Security & $\begin{array}{l}\text { 4.1 Protection of the device } \\
\text { Protect devices and digital content. Understand the risks and } \\
\text { threats in the digital environment. Be aware of data security } \\
\text { measures. }\end{array}$ \\
\hline
\end{tabular}




\begin{tabular}{|c|c|}
\hline & $\begin{array}{l}\text { 4.2 Protection of personal data and ensuring confidentiality } \\
\text { Protect personal data and privacy in the digital environment. } \\
\text { Understand how to use personal information to prevent } \\
\text { damage. }\end{array}$ \\
\hline & $\begin{array}{l}\text { 4.3 Protection of health and well-being } \\
\text { Avoid health risks and threats to physical and psychological } \\
\text { health in the process of using digital technologies. Be able to } \\
\text { protect yourself and others from potential dangers in the } \\
\text { digital environment. Be aware of digital technologies for } \\
\text { social well-being and integration. }\end{array}$ \\
\hline & $\begin{array}{l}\text { 4.4 Environmental protection } \\
\text { Be aware of the environmental impacts of digital technology. }\end{array}$ \\
\hline $\begin{array}{l}\text { 5. Problem } \\
\text { solving }\end{array}$ & $\begin{array}{l}\text { 5.1 Solution of technical problems } \\
\text { To be able to identify technical problems that arise during the } \\
\text { work with digital devices and solve them (from } \\
\text { troubleshooting to solving more complex problems) }\end{array}$ \\
\hline & $\begin{array}{l}\text { 5.2 Determination of needs and technological solutions } \\
\text { Identify needs and select the necessary digital tools to solve } \\
\text { them. Customize digital environments for personal needs. }\end{array}$ \\
\hline & $\begin{array}{l}\text { 5.3 Creative use of digital technology } \\
\text { Use digital tools and technology to create knowledge and } \\
\text { innovation. Develop conceptual solutions to problematic } \\
\text { situations in digital environments. }\end{array}$ \\
\hline & $\begin{array}{l}\text { 5.4 Identification of gaps in digital competency } \\
\text { Understand which digital competencies need to be } \\
\text { developed. To be able to support others in developing their } \\
\text { own digital competence. Seek opportunities for self- } \\
\text { development in the digital environment }\end{array}$ \\
\hline
\end{tabular}

Formed: by authors

\subsection{Competency Target Model 2025}

The model creates a shift in focus from the narrowly understood computer fluency to ongoing emphasis on the development of composite, integrated skills of cooperation and communication in the digital environment. It is also important to consider digital skills in close connection with soft skills and general knowledge. This approach is illustrated by the Target Competency Model 2025 as shown in Figure 2.

In addition to the purely technical skills of working with digital devices, this model also includes cognitive and socio-behavioral competencies aimed at ensuring a comfortable existence, effective communication and selfdevelopment of a person in a digital environment. Based on these competencies, the main areas for development can be identified:

- digital skills and knowledge. For example, basic digital fluency, data analytics, machine learning, artificial intelligence, programming, IT systems architecture, and cybersecurity;

- $\quad$ skills and knowledge that help to cope with the volatility and uncertainty of the future. For example, adaptability, critical and systemic thinking, ability to cope with stress, change management, business planning, and self-learning ability according to the concept of 'lifelong learning'; 
- $\quad$ skills and knowledge that help to cope with a large flow of information, including basic skills in programming, search, processing and analysis of information, information hygiene, media fluency, as well as attention management;

- $\quad$ skills and knowledge that determine high communication abilities for effective interpersonal interaction. For instance, teamworking, cooperation, selfpresentation skills, and business negotiation skills, and skills and knowledge that cannot be mastered by machines, for example, empathy and emotional intelligence, creativity and creative thinking, and control of robotic processes.

\subsection{Change in working conditions and requirements for an employee}

The development of automated systems capable of complex physical actions, high rates of change in technology and the social environment transform the essence of human labor in all sectors of the economy. The employment structure will change. New professions will appear, and the demand for digital competence of workers will increase.

By 2022, as a result of the introduction of new technologies, 75 million jobs will disappear (WEF, 2018). Digitalization in the service sector will lead to the reduction in the staff involved in working with clients and processing data in back-offices. Jobs will be reduced in the field of administrative work. However, technological innovations will create an additional 133 million jobs in intelligent and high-tech areas related to new technologies, such as mobile technologies, artificial intelligence, big data and cloud technologies.

Only $9 \%$ of employees can be replaced by automated solutions. With the penetration of new technologies, it is expected that labor productivity will be growing by an average of $30 \%$ for the period 2015-2022. Automation poses a threat to both low-skilled and mid-level professionals, such as office workers, builders, machine tool operators (WEF, 2018). Figure 3 shows the change in employment in US industries from 1980 to 2015. Due to technological development, employment is growing among low- and highly-skilled workers, while it is decreasing among middle-skilled workers. Low-skilled personnel are still expensive to automate, and highly qualified personnel are still difficult to automate because of the complexity of the tasks. This is confirmed by the report of the Organization for Economic Cooperation and Development.

In OECD countries, the proportion of intermediate workers decreased from $49 \%$ to $40 \%$ for the period 1995-2015. For comparison: the share of highly and unskilled employees over the same period increased by $7.6 \%$ and $1.9 \%$, respectively. Already, various kinds of specialists working with IT systems are extremely in demand. These include UX designers, mobile and front-end developers, scrum masters and agile trainers, full stack developers, machine learning engineers and DevOps engineers. 


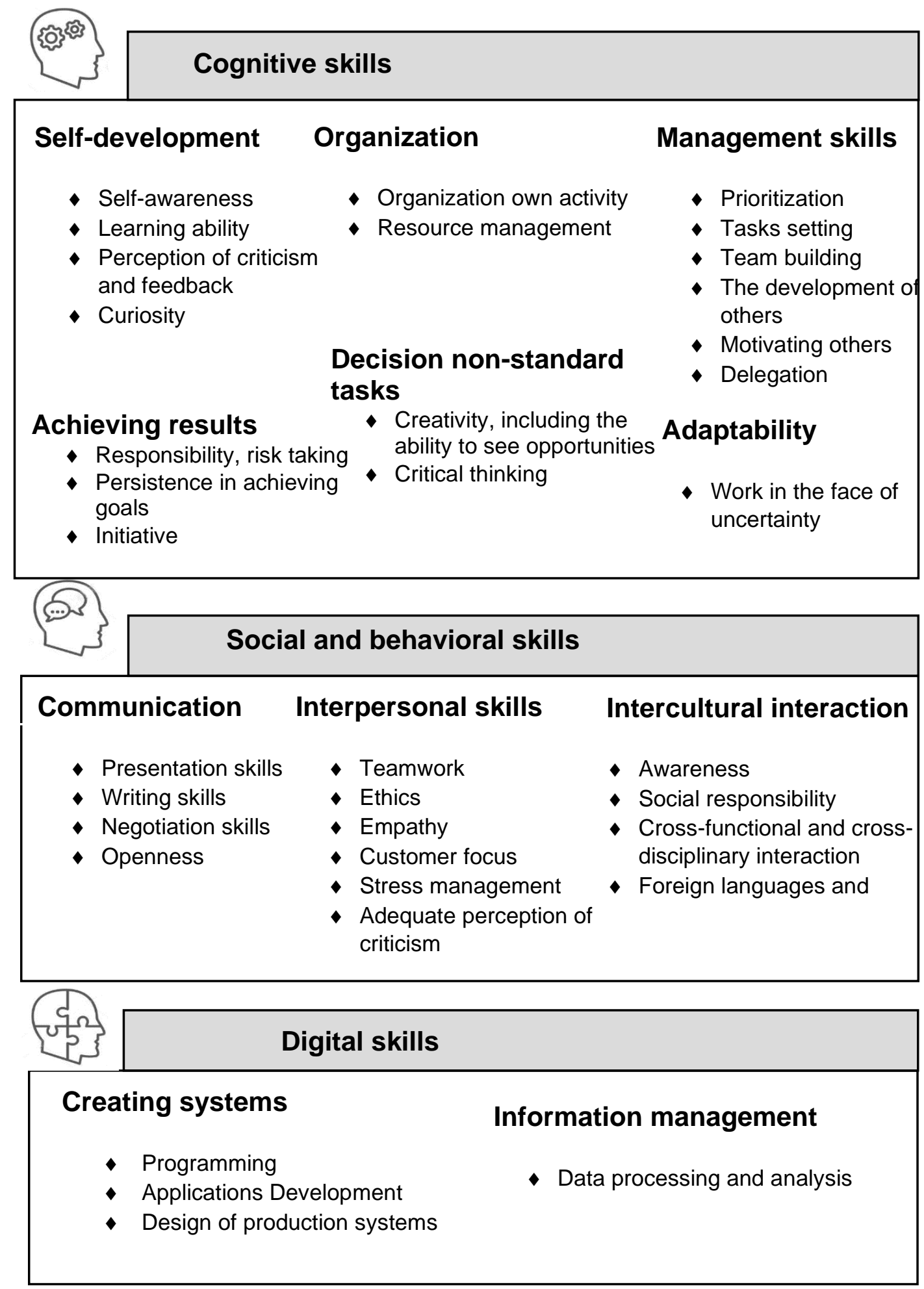

Figure 2: Target competency model 2025

Formed: by authors 


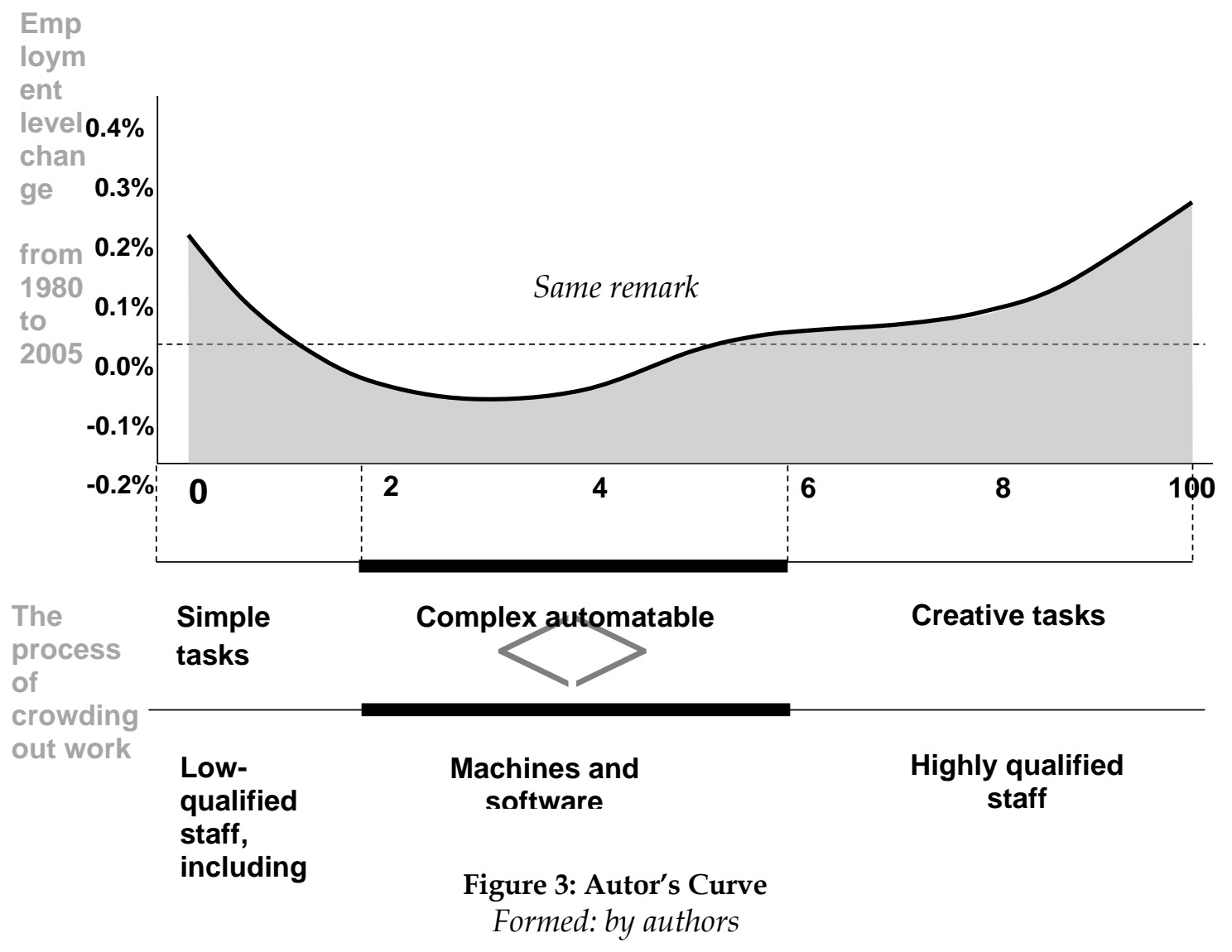

In light of rapid technological changes, companies will increasingly interact with complex digital ecosystems spanning a range of enterprises and technologies, using artificial (AI) intelligence, the Internet of Things (IoT) or automated devices in their work. This will lead to the emergence of new areas of employment and new professions, some of which may not even exist today. As can be seen from Figure 4, the distribution of a new profession in the market takes only between 15 and 20 years.

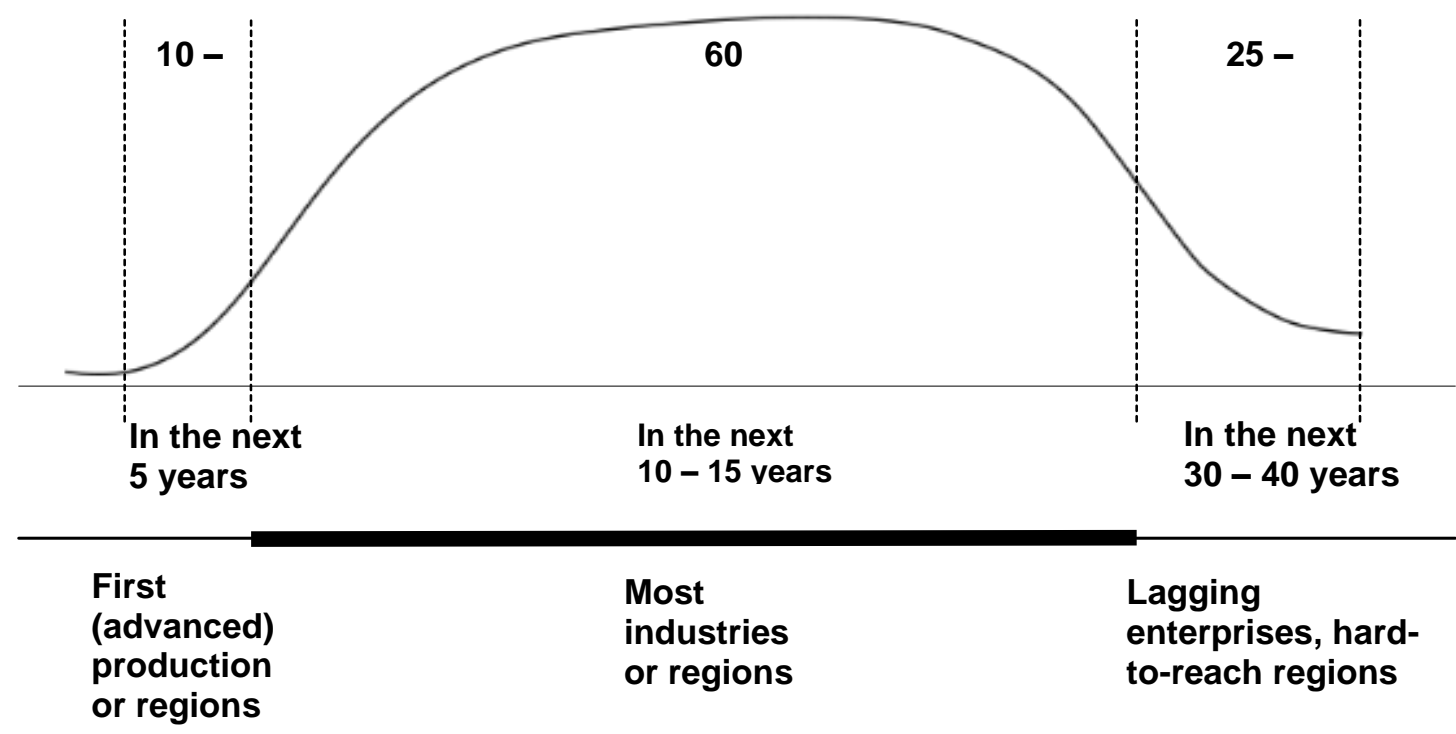

Figure 4: The process of retirement of the profession

Formed: by authors 


\subsection{New areas of employment}

The Atlas of New Professions predicts that, by 2030, 57 'traditional' professions will disappear, and 186 new ones will appear. According to forecasts, 65\% of today's schoolchildren and students will occupy positions that do not yet exist (IMD, 2018). By 2025, professions such as virtual living environment designers, technological ethics advocates, digital culture interpreters, freelance biohackers, and IoT data analysts are expected to be in high demand. At a later time, even more technologically advanced professions will appear including: space tour guides and personal content managers (Microsoft, 2018).

With the growth of automation, a call for the creation of new sectors will sharply increase, and at least four areas can be identified where significant changes can occur. The development of new generation technologies for industrial and consumer applications will revolutionise the technological sector. For example, the design and programming of smart energy networks and other smart systems for cities and households, or the production of urban robotics and unmanned autonomous vehicles, or the design and production of renewable bioengineering materials. There will be a growth in the demand for personalized services in the field of education, healthcare, experience design and entertainment. People will be spending more and more time in the virtual world through virtual reality systems, social networks and making use of virtual currencies. All these changes will lead to the creation of a new creative economy.

\section{New technologies in teaching digital skills}

Learning in the digital age will be continuous, social, personalized and focused on the needs and interests of the student. Educational decisions will be made on the basis of big data collected during previous training sessions (Kovtun et al., 2020). This means that there will be a significant change in the educational paradigm. This change does not necessarily mean that learning processes will be transferred into a digital environment. Instead, learning in the digital age will become a deeper transformation of the entire learning process. This will include the use of new digital tools to rethink how to teach and learn (Figure 5).

Technological innovations in the information environment (development of mobile networks, artificial intelligence, automation, advanced data analytics, etc.) make it possible to expand learning opportunities by combining traditional teaching methods with modern technologies, as in using algorithms to personalize learning experiences.

These processes are illustrated in a graph put forward by Capgemini Corporate University, illustrating the company's educational process. 


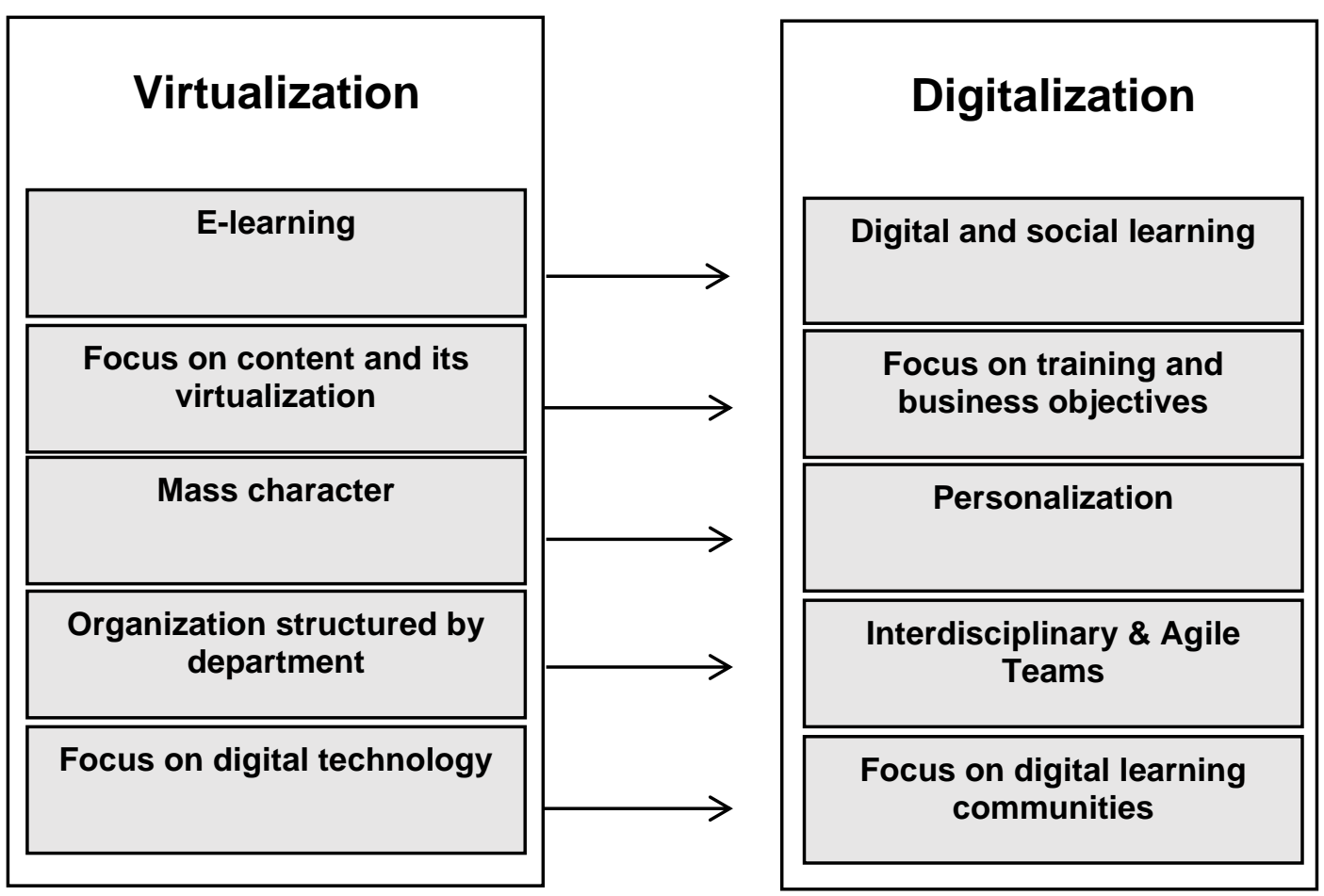

Figure 5: Using new digital tools

Formed: by authors

\subsection{Continuing education}

Most people still understand that formal education takes place at schools and universities. However, there are many other opportunities for acquiring knowledge and developing skills outside these traditional environments. A key factor in the competitiveness of the personality of a professional and company in the VUCA (Volatility, uncertainty, complexity and ambiguity) -world is the principle of continuing education. The underlying process is lifelong learning, which is a constant, voluntary and self-motivated search for knowledge for personal or professional reasons. Education can no longer be divided into place and time for acquiring knowledge. Instead, learning should be seen as a constant and everyday interaction with other people and with the world (EFMD, 2018).

Lifelong learning can be broadly understood as flexible, diverse, available at different (times and in different places. Lifelong learning requires the individual to not only to customize and get deeply adaptive, but also to get personalized training in mastering new skills, and to develop his or her critical mind to satisfy a diverse and context-sensitive learning needs with no age limit. According to the concept of "learning of the future" proposed by Levy E. an individual must master five skills in order to meet the demands of changes in the external environment (UNESCO, 2017). These are: learning to know which is not just awareness of the nature of information, mastery of learning tools, but also the acquisition of structured knowledge; learning to do which is the development of a set of skills for those types of work that are necessary now and will be necessary in the future, including innovation and adaptation of training to future working conditions; learning to live together and with others which includes constructive communication, peacefully resolving conflicts, 
discovering other people and their cultures, strengthening community potential, individual competence and abilities, economic sustainability and social integration; learning to be which is education that contributes to the comprehensive and full development of a person: mind and body, intelligence, sensitivity, aesthetic assessment, spirituality, etc, and learning to learn and continuing to learn throughout life.

\section{Lifelon}

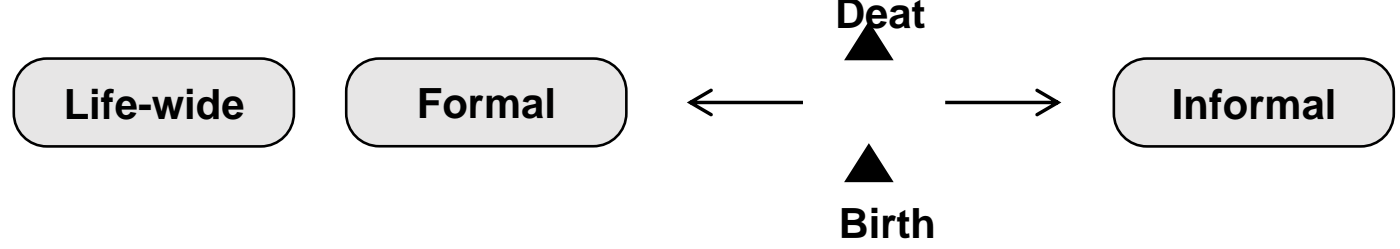

Figure 6: The concept of continuous and comprehensive training Is it training or education?

Formed: by authors

The National Agency for Education of Sweden has proposed the concept of continuing and comprehensive education as shown in Figure 6. The concept combines lifelong learning throughout a person's life and life-wide learning, which includes all types of training and personal development, both in the educational environment and in ordinary (non-educational) situations. It is determined by interests, the subjective value of training, as well as individual learning needs, which are manifested only in everyday activities, and involves a combination of formal and non-formal learning.

\subsection{Learning through experience}

An experiential learning approach has become widespread in education, especially in the corporate environment. This is a set of educational technologies that involve students in any activity and the gaining of relevant experience, as well as the evaluation of this activity and acquired experience, identification and assimilation of new knowledge and skills (Figure 7).

Educational technologies that underlie learning through experience are usually divided into three groups. Business simulations and games are training technologies in which processes, events, places, and situations are reproduced, which provides an interactive learning experience with a controlled level of risk. Business games are a type of simulation that includes game elements, such as history, goals, feedback, and the game itself. Training at the workplace in the normal course of work of the participant can be either structured (coaching, mentoring, etc.), or unstructured (sharing knowledge during work or observing others). 


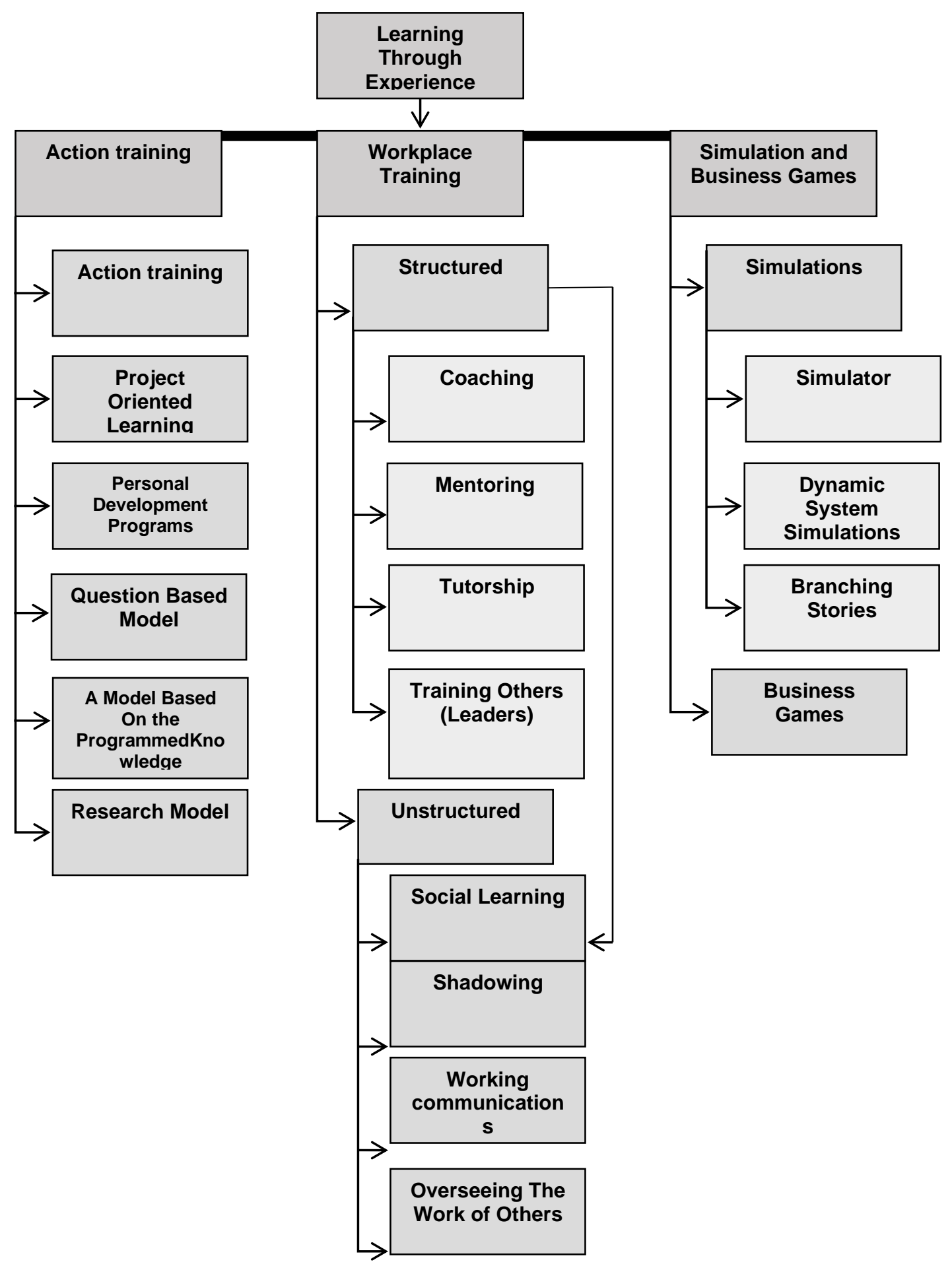

Figure 7: Learning technologies through experience Formed: by authors

Learning by action is when individual participants or teams complete tasks and learn in the process of developing solutions to real business problems and situations. Most learning models which are based on experience consist of learning cycle of two to five steps. The classical model of learning theory 
through experience, developed by David Kolb offers four stages of learning as shown in Figure 8 . The learning process can begin with any of the stages, but most often starts with immediate or specific experiences, which is the basis for observation and reflection.

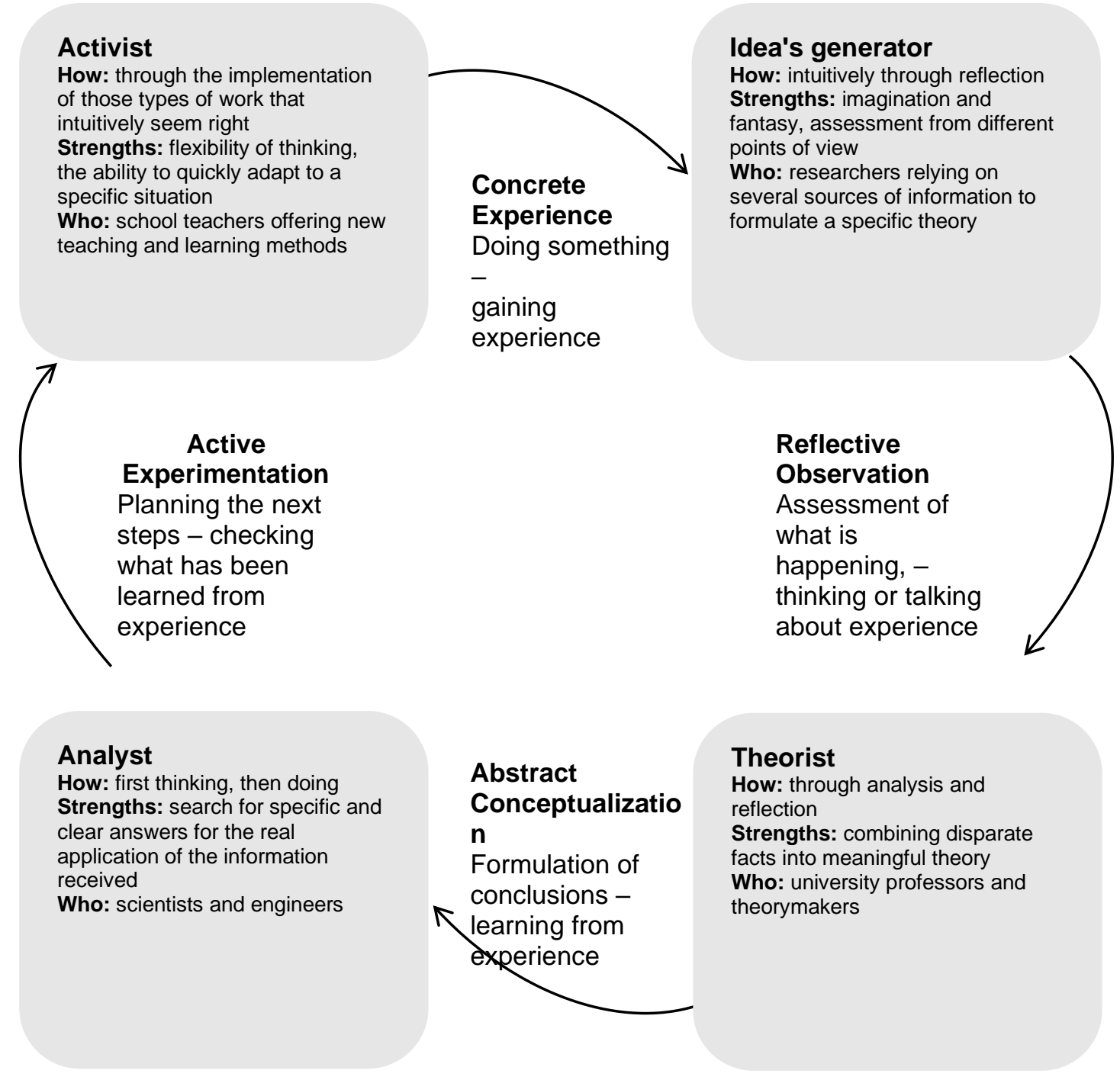

Figure 8: ELT Learning Cycle

Formed: by D. Kolba

\section{Dissemination of training through experience in corporate practice}

In 2016, the Association for Talent Development (ATD) conducted a large-scale study of the educational sphere, in which 270 companies took part. Threequarter of them were commercial enterprises and the rest were state and nonprofit organizations. Sixty percent of these companies has more than 1000 employees. It turned out that learning through experience is used by $76 \%$ of these organisations (ATD, 2016). Among them, 69\% use this approach to train 
their managers.To evaluate learning outcomes through experience, more than half of the respondents monitor students' satisfaction with the learning process, and also focus on the usefulness of the acquired skills for students and evaluate the change in business indicators related to the direction of training (Figure 9).

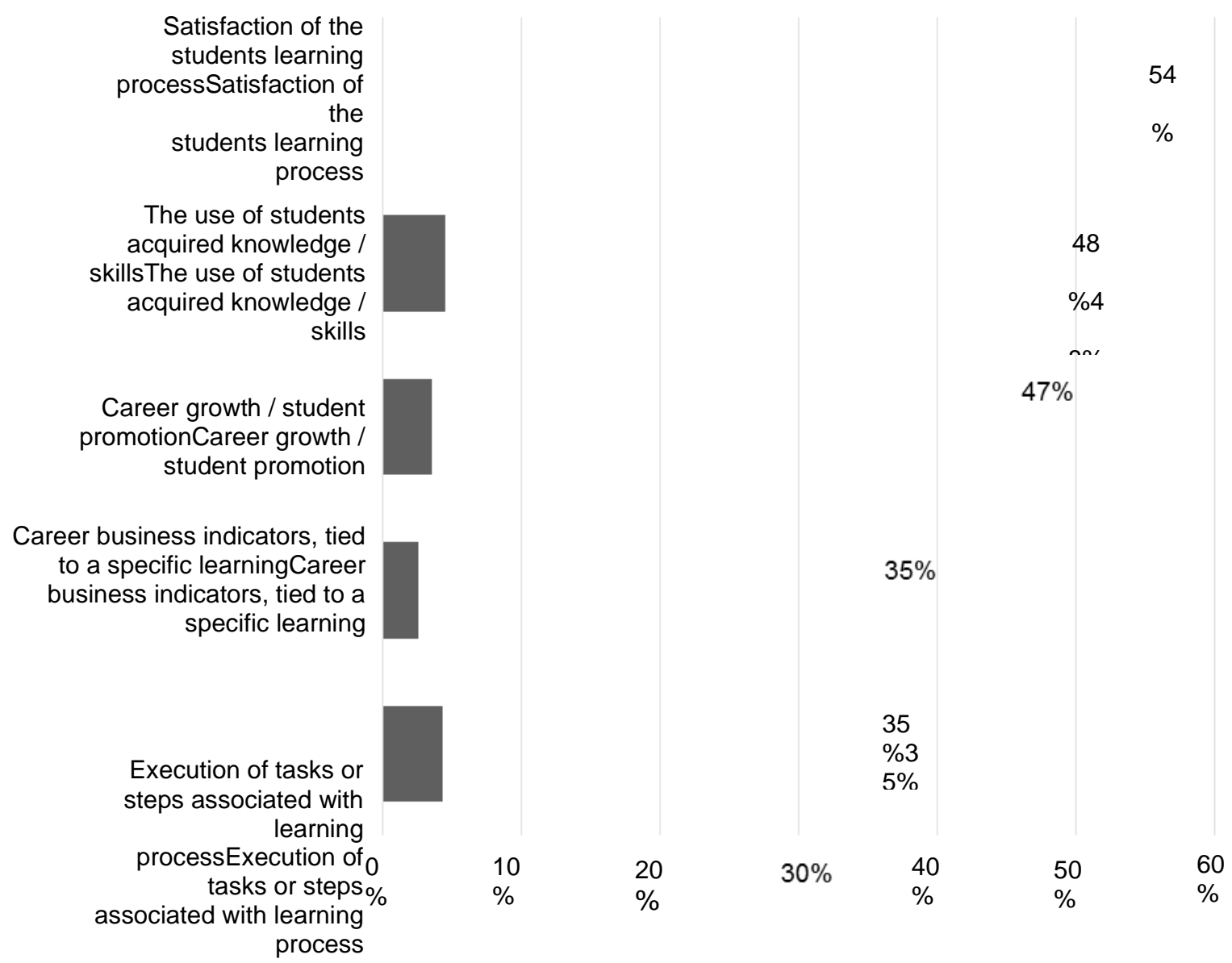

Figure 9: Indicators for assessing the effectiveness of training through experience (\% of respondents)

Formed: by authors

\subsection{Social learning}

Social learning is the exchange of information and experience, collaboration and joint creation of content between and within networks (both employees and external individuals) using interactive discussions and social media based on digital technologies. Social learning is acquired by corporate social networks that implement the functionality of microblogging, knowledge sharing, group chats and interactive notifications. Social training at the company significantly speeds up the creation and delivery of educational content to students (time-to-market) and, accordingly, makes training more flexible. Furthermore, the use of social 
learning approaches allows training to be carried out when it is necessary, and not when the program is scheduled to start, which is called just-in-time learning. It provides informal training opportunities and stimulates a wide collaboration of employees, effectively involving all employees in training. Finally, the introduction of social learning optimizes the work of the learning departments and allows you to focus on the result, as shown in Table 2.

Table 2: Social Learning with Microsoft Learning as an Example

\begin{tabular}{|c|c|}
\hline No longer our job & Our job \\
\hline $\begin{array}{ll}\checkmark & \text { manage trainers } \\
\checkmark & \text { conduct hundreds of trainings } \\
\text { for } 30 \text { people in a class } \\
\checkmark \quad \text { support passive learning }\end{array}$ & $\begin{array}{l}\checkmark \quad \text { use technology to scale } \\
\checkmark \quad \text { provide easy access to advanced } \\
\text { knowledge } \\
\checkmark \quad \text { teach "learn by doing" and share } \\
\text { experiences }\end{array}$ \\
\hline $\begin{array}{l}\text { be experts } \ldots \\
\ldots \text { and coach everyone } \ldots \\
\ldots \text { for each topic }\end{array}$ & $\begin{array}{l}\checkmark \quad \text { meet the goals of the business and its } \\
\text { transformation } \\
\checkmark \quad \text { set limits and become obsessed with } \\
\text { quality organize coaching and trainee } \\
\checkmark \quad \text { ommunities }\end{array}$ \\
\hline $\begin{array}{l}\checkmark \text { create all content yourselves } \\
\checkmark \quad \text { let anyone publish anything in } \\
\text { any format } \\
\checkmark \quad \text { measure the number of views } \\
\text { and downloads }\end{array}$ & $\begin{array}{ll}\checkmark & \text { organize a community of authors } \\
\checkmark & \text { highlight data-driven } \\
\checkmark & \text { do less, but better }\end{array}$ \\
\hline
\end{tabular}

Formed: by authors

Forrester (ATD, 2016). has developed a way to evaluate the overall economic effect of various social learning systems. Under their model, productivity growth through time saving is calculated. Firstly, the more involved an employee becomes, the less time he spends on fulfilling his routine duties, such as searching for information and conducting meetings, etc. Secondly, the better the communication in the company, there is duplication of projects and these are implemented at lower cost. And, thirdly, social adaptation reduces the cost of training new employees. According to a conservative estimate by Forrester, a highly involved employee saves 30 hours, while an average employee saves 15 hours a year. Thus, by measuring the activity of users in the network, we can make an assessment of the increase in productivity (ATD, 2016). ATD offers the following key metrics for assessing the effectiveness of social learning (ATD, 2011): frequency of access to individual training materials; activity in online learning communities; the popularity of custom content; connection with business goals and KPI; variety of types of user content; frequency of adding content; frequency of use of individual social media tools; behavioral characteristics of users who share content; polls of employee satisfaction with social learning; and connection with individual goals.

\subsection{Flipped learning}

A relatively new approach is flipped learning, which is a learning technology for the direct transfer of knowledge from a group educational space to an individual one. The group learning space is transformed into a dynamic and interactive environment in which the teacher takes on the role of facilitator, mentor, tutor, 
consultant and helps students put theory into practice, develop skills and deeply reflect on the subject for further independent training and development (Figure $11)$.

The key components of the technology of the flipped class are: 1) an online platform for communication in connection with educational content; 2) interactive instructions and simulators for working in typical educational contexts; 3) providing monitoring systems for teachers and management for the purpose of feedback to employees; 4) feedback forms for students with the purpose of operational correction of training programs (Batista-Foguet et al., 2009).

The core of any flipped learning is the flipped classroom. The flipped classmodel' appeared in the practice of American school education to prepare a didactic material for home study in the format of video lessons and presentations. Thus, more time could be devoted during the face-to-face lesson for the development of problem solving skills, group interaction, cooperation, the application of knowledge and skills in a new situation, as well as the creation presentations and application of a new educational product by the students.

The flipped class is one of the models of blended learning aimed to expand the possibilities of individualizing education, which takes into account the educational needs, interests and abilities of students, in which the teacher acts as an assistant and mentor. The introduction of e-learning formats does not reduce the importance of face-to-face sessions. Full-time classes are great for group discussions, for working with small and medium-sized businesses and other close interactions. In the flipped model, the theoretical material can be completely moved to online, while all practical tasks, possibly in a playful way, get extra time in the classroom.

In most organizations where LMS systems exist, it is possible to determine the most successful employees in terms of training speed. These students can be quickly involved in the classroom in the process of sharing their already acquired knowledge and train their comrades. McAfee Corporation adopted the 'flipped class' approach to reform the initial training camp program for hiring new employees (Wasfy,et. al, 2013 ).

\subsection{Gamification}

Gamification is the practice of applying approaches specific to games in nongame processes in order to attract students and increase their involvement in solving learning problems. It is based on the use of scenarios that require user attention and real-time response (Figure 11).

The learning process includes scenario elements specific to the game, such as scoring, difficulty and skill levels, awards, statuses, ratings, progress indicators, competitions between participants, virtual currencies, etc. 
What system should be implemented as part of the gamification of the company?
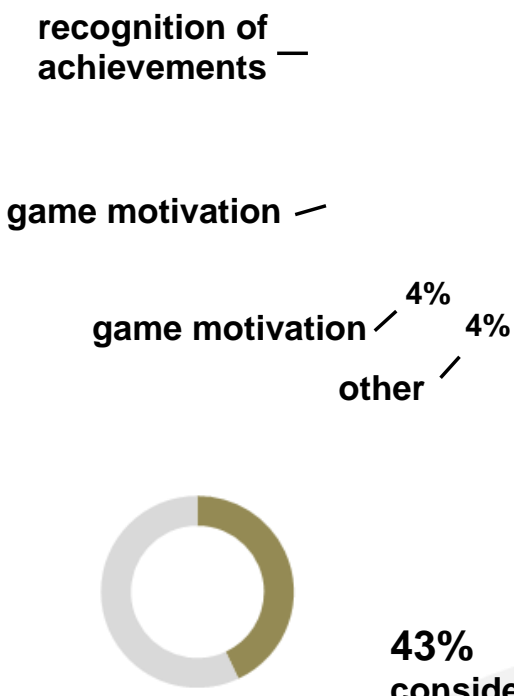

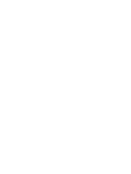

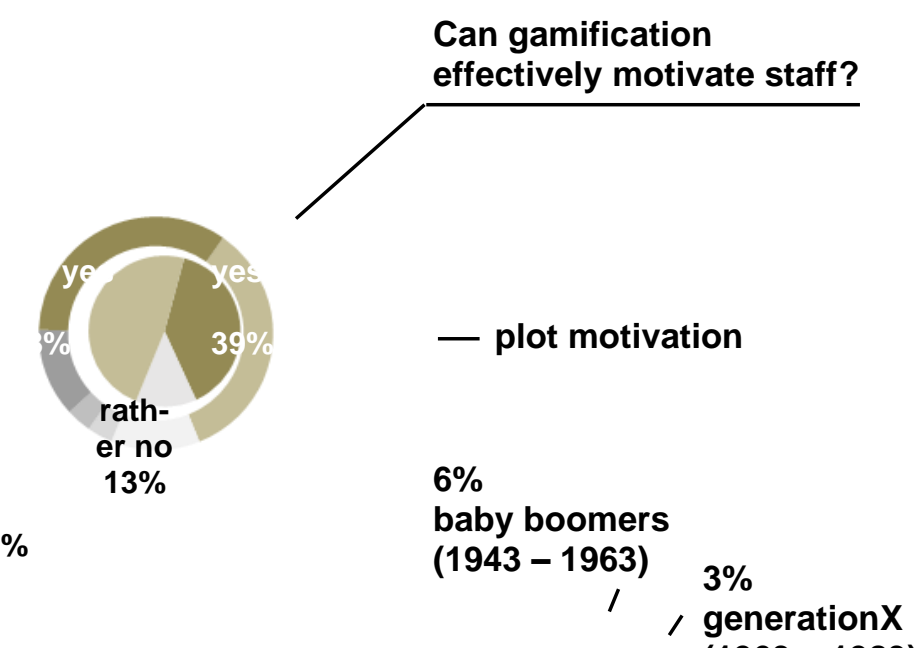

(1963 - 1983)

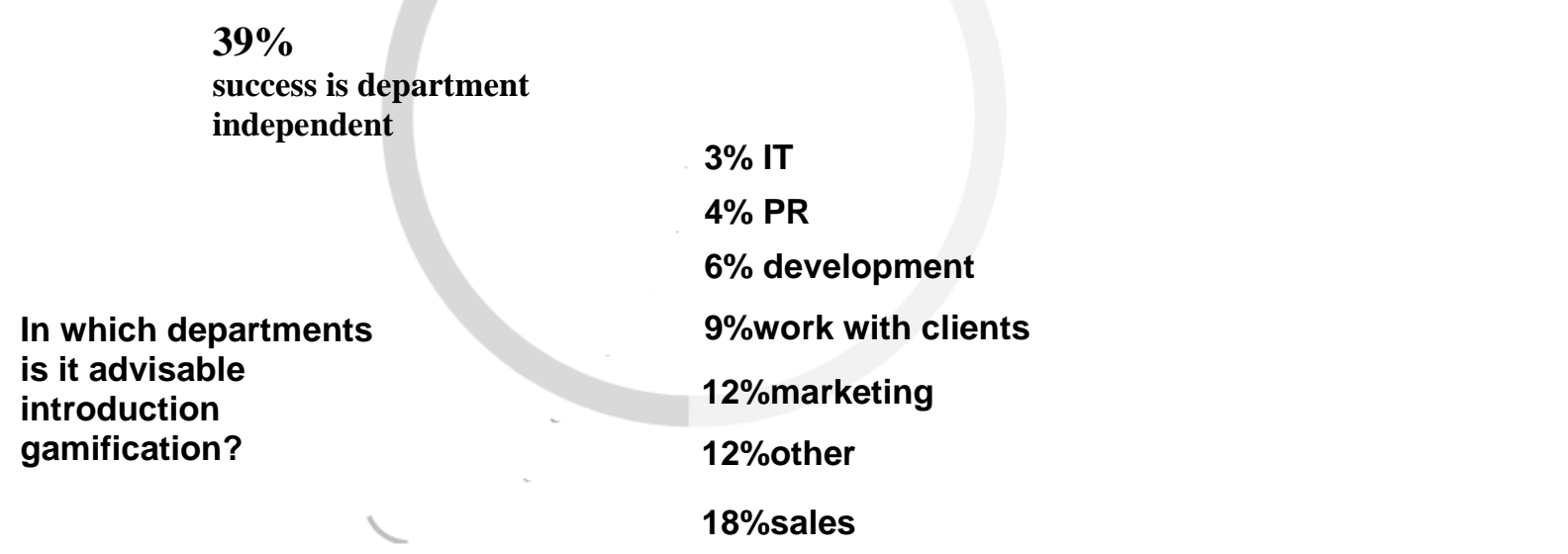

$38 \%$ generationZ (2003- 20120

\section{$43 \%$}

consider that it is most

effective to immerse all

employees in the game

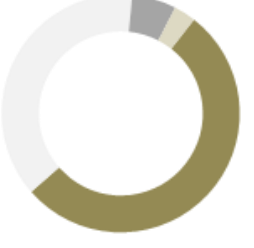

$-53 \%$

generation $Y$

(1983 - 2003)

Figure 11: Gamification in Ukrainian companies Formed: by authors

In general, gamification is aimed at creating a common gaming experience contributing to the student's emotional involvement. According to polls, almost $90 \%$ of business representatives recognize gamification as effective in motivating staff, whereas $39 \%$ believe that the success of its use does not depend on the department and direction of activities (Levy et al., 2003). The implementation of game approaches in the educational process extends from the partial introduction of game-type elements into the educational trajectory to the complete immersion of all educational activities in the game context. For example, Minecraft has been successfully modified in Russia, the USA, 
Australia, Sweden and other countries in order to achieve specific educational goals (Mirrlees et al.2020,). Minecraft has developed a special training module that adapts to the needs of basic and corporate training. Some existing video games can be adapted for training, thus, Masaryk University in the Czech Republic uses the computer game Kingdom Come: Deliverance in Class. In the context of corporate training, gamification functions are determined by the need to give employees the opportunity to develop leadership skills, provide noninvasive forms of teamwork assessment, and maintain a general level of motivation for effective participation in business processes.

The main idea is to borrow the spirit of the game, which can unite people to form a community that can provide support and assistance to all participants. Amway (Bakhshi et al.2020,) has developed a special online simulator for front office employees. The design of the simulator involved an online championship on cleaning various types of facilities using company cleaning products. The results collected after the championship showed that, for employees of regional departments, the overall sales growth was $80 \%$ higher than the achievements of those who had traditional face-to-face training (Andriushchenko et al. 2019b).

In cases where users cannot concentrate on educational material for a long time, the use of gamification allows the transfer of educational content into current business operations or production processes. At the same time, gamification is also an effective way of outsourcing certain production and technological tasks to an external audience. A case in point is the use of the Foldit game (Hatlevik et al., 2015). During this game, users were asked to solve a sequential series of puzzles, which, together, allowed them to successfully solve the problem of protein folding. Interpose has introduced the use of special game currency (Claro et al., 2012). Initially, a special price list was formed, according to which each employee could earn a certain amount of game currency for over-fulfilling a sales plan or a proposal to optimize business processes. Earned units of game currency cannot be exchanged for national currency, but can be used to purchase various gifts and conduct leisure activities for family members.

\subsection{Chatbots}

The use of machine learning algorithms allows organisations to optimize the training processes for employees. Retail companies working with a large array of repetitive requests can make use of smart chatbots.

The advantages of bots are the ease of interaction with them, the speed of their reaction and the ability to configure them for the user. Using the bot greatly simplifies the interaction with services by providing a universal interface.

Separately, IVR bots can be distinguished. These are the same chatbots, but with a changed interface: when synthesis and recognition systems are being connected, standard chat is transferred into voice format. Connecting emotion analytics systems and communication strategies to the IVR bot allows each employee to work out custom KPIs specified with respect to their effectiveness zones. 


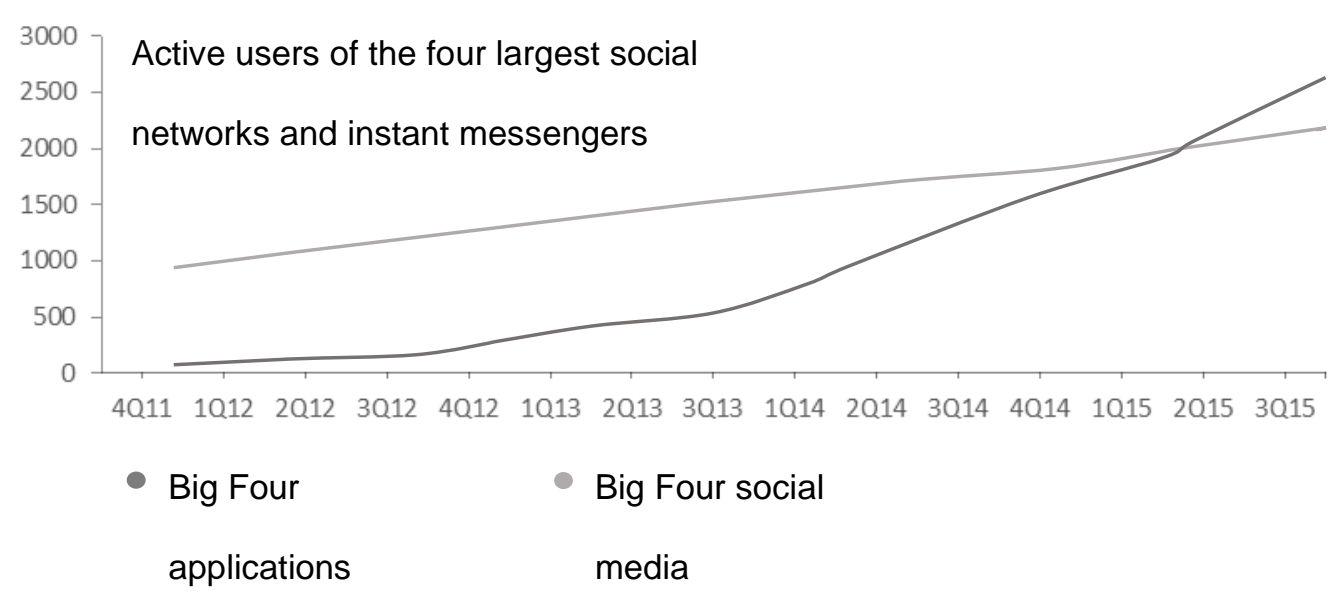

Figure 12: Messenger applications overtake social networks Formed: by authors

The array of information accumulated by chatbots allows you to visualize the idea of the best work practices across the organization as a whole and apply this knowledge in training. By laying the elements of gamification on this process, it is possible to launch competitive formats of personnel certification based on the results of training sessions. The specific errors in the operation of chatbots and IVR bots depend on the rate of equipment of the call center, the accuracy of the tasks for fuzzy search, the rate of the recognition system and the audience of callers (Andriushchenko et al. 2019c).

\section{Conclusion}

To solve current problems in the field of education, the training system for high digital competency cadres should undergo decisive changes. In the context of globalization processes, the priority for innovative business development is the vector of digitalization. The effective functioning of the subjects of market relations is possible, due to the identification of alternative competitive development strategies, taking into account digital trends. In this context, the key point is the rapid adaptation of digital technologies into the economic activities of economic entities. The digital revolution has become a powerful driver of innovative business development. Digitalization encourages market participants to explore 'unknown territories', and the corresponding transformation serves as a driver of prosperity for the development of innovative entrepreneurship. The relevant trends require the study of innovative business models and the search for new sources of attraction and generation of intellectual resources. It is unlikely that corporate leadership, in its present form will survive the digital revolution. Therefore, it is necessary to radically change management priorities and use dynamic opportunities, which will allow organisations to gain competitive advantages over their competitors. Therefore, the digital revolution can become both a utopian for the development of innovative business, or a prerequisite for survival in the market. Digital transformations will lead the subjects of market relations to achieve a high level 
of innovation, competencies, efficiency, leadership and responsibility with fundamentally positive results for companies and societies.

The rate of knowledge of such skills will determine the success of a person's life and the prospects of his or her employment. This study revealed a tendency to demand skills adaptive and digital skills from professionals. The development of digital fluency affects the quality of work of employees. The ability to combine various educational technologies, training formats and technical innovations into a single educational system is the hallmark of a talented employee. It is also important to balance the traditional models of full-time study with mobile technologies, augmented reality tools and other digital educational tools. An appropriate distribution of responsibilities between teachers and digital learning support tools is crucial. The quality of digital education can be improved through better data analysis and forecasting, development and launch of advanced educational products using artificial intelligence, improving forecasting tools to understand the relationship of digital transformation in various departments and ensure their interaction.

\section{References}

Ahmad, M., Karim, A. A., Din, R., \& Albakri, I. S. M. A. (2013). Assessing ICT competencies among postgraduate students based on the 21st century ICT competency model. Asian Social Science, 9(16), 32-39.

Ananiadou, K., \& Claro, M. (2009). 21st Century skills and competences for new millennium learners in OECD countries. OECD Education Working Papers, No. 41. OECD Publishing. http://doi.org/10.1787/218525261154

Aesaert, K., Nijlen V. D., Vanderlinde, K., \& Van Braak, J. (2014). Direct measures of digital information processing and communication skills in primary education: Using item response theory for the development and validation of an ICT competence scale. Computers \& Education, 76, 168-181. http://doi.org/10.1016/j.compedu.2014.03.013

Andriushchenko, K., Buriachenko, A., Rozhko, O., Lavruk, O., Skok, P., Hlushchenko, Y., Muzychka, Y., Slavina, N., Buchynska, O., \& Kondarevych, V. (2020). Peculiarities of sustainable development of enterprises in the context of digital transformation. Entrepreneurship and sustainability issues, 7(3), 2255-2270. http://doi.org/10.9770/jesi.2020.7.3(53)

Andriushchenko, K., Lavruk, V., Uliganets, S., Kovtun, V., \& Matviienko, H. (2019a). Reputation risk management companies based on competence approach. TEM Journal, 8(2), 516-524. http://doi.org/10.18421/TEM82-27

Andriushchenko, K., Rudyk, V., Riabchenko, O., Kachynska, M., Marynenko, N., Shergina, L., Kovtun,V., Tepliuk, M., Zhemba, A., \& Kuchai, O. (2019b). Processes of managing information infrastructure of a digital enterprise in the framework of the «Industry 4.0» concept. Eastern-European Journal of Enterprise Technologies, 1(3), 60-72. http://doi.org/10.15587/17294061.2019.157765

Andriushchenko, K., Tepliuk, M., Boniar, S., Ushenko, N., \& Liezina, A. (2019c). Influence of cost drivers on value-oriented management of investment activity of companies. Investment Management and Financial Innovations, 16(3), 353-364. http://doi.org/10.21511/imfi.16(3).2019.31

ATD. (2011) How Does Social Learning Measure Up?. Retrieved from: https://www.td.org/magazines/td-magazine/how-does-social-learningmeasure-up 
ATD. (2016) "Training Industry Report". Retrieved from: https://trainingmag.com/sites/default/files/images/Training_Industry_Repor t_2016.pdf

Bakhshi, H., Freeman, A., \& Higgs, P. (2012). A dynamic mapping of the UK's creative economy. London, UK: NESTA. Retrieved from: https://eprints.qut.edu.au/82040/1/geography_uks_creative_hightech_economieswv20151.pdf

Carnevale, A. P., \& Smith, N. (2013). Workplace basics: The skills employees need and employers want. Human Resource Development International, 16(5), 491-501. http:/ / doi.org/10.1080/13678868.2013.821267

Chivu, R. G., Turlacu, L.-M., Stoica, I., \& Radu, A.-V. (2018). Identifying the effectiveness of e-learning platforms among students using Eye-Tracking technology. Proceedings for the International Conference on Higher Education Advances (HEAd'18), 621-628. http://dx.doi.org/10.4995/HEAd18.2018.8046

Claro, M., Preiss, D. D., San Martín, E., Jara, I., Hinostroza, J. E., \& Valenzuela, S. (2012). Assessment of 21st century ICT skills in Chile: Test design and results from high school level students. Computers \& Education, 59(3), 1042-1053 http://doi.org/10.1016/j.compedu.2012.04.004.

EFMD. (2018). - Digital age learning. Special interest group report. Retrieved from: http://www.efmd.org/images/stories/efmd/downloadables/Corporate_Advi sory/2017/5a_SIG_DAL_Report.pdf

Eshet-Alkalai, Y. (2004). Digital literacy: A conceptual framework for survival skills in the digital era. Journal of Educational Multimedia \& Hypermedia, 13(1), 93-107. Retrieved from: https://www.openu.ac.il/personal_sites/download/Digitalliteracy2004-JEMH.pdf

European Union. (2018). Digital Education Action Plan. (2018). Retrieved from: https://ec.europa.eu/education/policy/strategic-framework/educationtechnology_en

Hatlevik, O. E., Ottestad, G., \& Throndsen, I. (2015). Predictors of digital competence in 7th grade: A multilevel analysis. Journal of Computer Assisted Learning, 31(3), 220 231. http:/ / doi.org/10.1111/jcal.12065

IMD. (2018). World digital competitiveness rating. Retrieved from: https:/ / www.imd.org/wcc/world-competitiveness-center-rankings/worlddigital-competitiveness-rankings-2018/

Ibrahim, N. N., Ayub, A. F. M., Yunus, A. S. M., Mahmud, R., \& Bakar, K. A. (2019). Effects of higher-order thinking module approach on pupils performance at primary rural school. Malaysian Journal of Mathematical Sciences, 13(2), 211-229. https://doi.org/10.5901/mjss.2015.v6n2p494

Khodabakhszadeh, H., Hosseinia, M., Abedi M. H., \& Ahmadi, F. (2018). EFL Teachers' Creativity and Their Teaching's Effectiveness: A Structural Equation Modelling Approach. International Journal of Instruction, 11(1), 227-238. https://doi.org/10.12973/iji.2018.11116a

Katz I. (2007). Testing information literacy in digital environments: ETS's iSkills assessment. Information Technology and Libraries, 26(3), 312. https://doi.org/10.6017/ital.v26i3.3271

Kefela, G. T. (2010). Knowledge-based economy and society has become a vital commodity to countries. International NGO Journal, 5(7), 160-166. Retrieved from: http://www.academicjournals.org/app/webroot/article/article1381828238_Ke fela.pdf

Kovtun, V., Andriushchenko, K., Horbova, N., Lavruk, O., \& Muzychka, Y. (2020). Features of the Management Process of Ambidextrous Companies. TEM Journal, 9(1), 221-226. http:/ / doi.org/10.18421/TEM91-31 
Lanvin, B., \& Kralik, M. (2009). E-skills: Who made that big dent in my flat world? Information Technologies and International Development, 5(2), 81-84. Retrieved from: https:// www.academia.edu/23530242/E-

Skills_Who_Made_That_Big_Dent_in_My_Flat_World

Lanvin, B., \& Passman, P. (2008). Building e-skills for the information age. Global Information Technology Report 2007-2008: Fostering innovation through networked readiness. Hampshire: Palgrave Macmillan, 77-80. Retrieved from: https://www.palgrave.com/gp/book/9781403999320

Lewin, C., \& McNicol, S. (2015). Supporting the development of 21st century skills through ICT. Key competencies in informatics and ICT, 98-181. Retrieved from: https://publishup.uni-potsdam.de/opus4ubp/frontdoor/deliver/index/docId/7032/file/cid07.pdf

Levy E., \& Murnane R. (2003). The skill content of recent technological change: An empirical exploration. The Quarterly Journal of Economics, 118(4), 1279-1333. http://doi.org/10.1162/003355303322552801

Moller, L., Robison, D., \& Huett, J. B. (2012). Unconstrained Learning: Principles for the Next Generation of Distance Education. The Next Generation of Distance Education. Boston, MA: Springer. https://doi.org/10.1007/978-1-4614-1785-9_1

McKinsey Global Institute. (2018). AI, automation, and the future of work: Ten things to solve for. Retrieved from: https://www.mckinsey.com/featured-insights/future-oforganizations-and-work/ai-automation-and-the-future-of-work-ten-things-tosolve-for

Mirrlees, T., \& Alvi, S. (2020). Automating Higher Education: Taylorism and the Teaching Machines. Selling, Automating and Globalising Higher Education in the Digital Age. New York: Routledge. https://doi.org/10.4324/9780429343940

Microsoft. (2018). Future Proof Yourself. Tomorrow's jobs. Retrieved from: https://enterprise.blob.core.windows.net/whitepapers/futureproof_tomorrows _jobs.pdf

UNESCO. (2017). Working Group on Education: Digital skills for life and work. Retrieved from: http:// unesdoc.unesco.org/images/0025/002590/259013e.pdf

Van Deursen, A. J. A. M., Helsper, E. J., \& Eynon, R. (2016). Development and validation of the internet skills scale (ISS). Information Communication \& Society, 19(6), 804823. http://dx.doi.org/10.1080/1369118X.2015.1078834

Van Deursen, A. J. A. M., \& Van Dijk, J. A. G. M. (2010). Measuring internet skills. International Journal of Human- Computer Interaction, 26(10), 891-916. http://dx.doi.org/10.1080/10447318.2010.496338

Voogt, J., \& Roblin, N. P. (2012). A comparative analysis of international frameworks for 21st century competences: Implications for national curriculum policies. Journal $\begin{array}{llll}\text { of Curriculum } & \text { Studies, }\end{array}$ http://dx.doi.org/10.1080/00220272.2012.668938

Wasfy, H. M., Wasfy, T. M., Mahfouz, R. M., \& Peters, J. (2013). The Education Sector Revolution: The Automation of Education. In Proceedings of the 120th ASEE Annual Conference \& Exposition. United States.

WEF. (2018). The Future of Jobs. Retrieved from: https://www.weforum.org/reports/thefuture-of-jobs-report-2018 